\section{NOVA TELLVS}

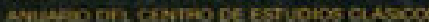

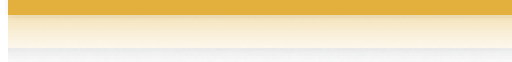

Nova Tellus

ISSN: 0185-3058

novatelu@servidor.unam.mx

Centro de Estudios Clásicos

México

Olivares Chávez, Carolina

Jenofonte y su recuerdo de Sócrates: algunos apuntes

Nova Tellus, vol. 27, núm. 2, 2009, pp. 149-180

Centro de Estudios Clásicos

Distrito Federal, México

Disponible en: http://www.redalyc.org/articulo.oa?id=59115485006

- Cómo citar el artículo

- Número completo

- Más información del artículo

- Página de la revista en redalyc.org

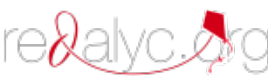

Sistema de Información Científica

Red de Revistas Científicas de América Latina, el Caribe, España y Portugal

Proyecto académico sin fines de lucro, desarrollado bajo la iniciativa de acceso abierto 


\title{
Jenofonte y su recuerdo de Sócrates: algunos apuntes
}

\author{
Carolina Olivares ChÁvez \\ Universidad Nacional Autónoma de México \\ caro@servidor.unam.mx
}

RESUMEN: Sócrates sigue siendo una figura sumamente enigmática para los estudiosos modernos, que en su mayoría han visto en Platón la fuente más confiable para reconstruir la enseñanza de este filósofo ágrafo, dejando de lado el testimonio de Jenofonte, que es considerado de menor valor. Con base en los estudios de Luccioni, Souto Delibes y Salay este trabajo se propone hacer algunas observaciones someras sobre la imagen de Sócrates que la crítica actual desprende de los escritos socráticos de Jenofonte.

$$
* * *
$$

ABSTRACT: Socrates continues to be a highly puzzling personage for modern scholars, most of which have seen in Plato the most reliable source for the reconstruction of this philosopher's unwritten teaching, thus leaving aside Xenophon's own testimony on the assumption of its lesser worth. Based on the researches done by Luccioni, Souto Delibes and Salay, this study aims at making some passing remarks on the image of Socrates that modern day critics can get from Xenophon's Socratic writings.

Palabras ClaVe: Sócrates, Jenofonte, Apología, Económico, Memorables, Simposio, Luccioni, Souto Delibes, Salay.

KeYwords: Socrates, Xenophon, Apology, Oeconomicus, Memorabilia, Symposium, Luccioni, Souto Delibes, Salay.

RECEPCIÓN: 24 de agosto de 2009.

ACEPTACIÓN: 19 de octubre de 2009. 


\title{
Jenofonte y su recuerdo de Sócrates: algunos apuntes*
}

\author{
Carolina Olivares Chávez
}

Desde la antigüedad, Sócrates ha pasado a la historia como un hombre sumamente enigmático, cuya vida y pensamiento siguen cautivando a los estudiosos, quienes eligieron a Platón como la mejor fuente para formarse una idea de cómo era el filósofo ágrafo. En consecuencia, los datos que sobre este personaje proporciona Jenofonte a menudo han sido considerados menos fiables. Sin embargo, conviene señalar que en años recientes varios especialistas han centrado su atención en las obras socráticas compuestas por este autor. Si bien hay numerosas investigaciones relacionadas directamente con el hijo de Sofronisco, en mi opinión destacan la de Luccioni titulada Xénophon et le socratisme (1953), la tesis doctoral de Souto Delibes denominada La figura de Sócrates en Jenofonte (2000), y el excelente análisis desarrollado por Salay en Socrates the whipping post: Xenophon's portrayal of Socrates as a Rebuke of Athenian Society (2004). Con base en dichos trabajos y, sobre todo, en la lectura de los escritos de Jenofonte, pretendo rescatar la imagen que él nos transmite de su maestro. Es preciso aclarar que, debido a que el tema de Sócrates es inagotable, lo que expongo a continuación son sólo algunas notas.

\footnotetext{
* Este trabajo fue presentado originalmente como ponencia en el II Coloquio de la Asociación Mexicana de Estudios Clásicos y es parte de mi proyecto doctoral titulado "Jenofonte: su doctrina de paideia a la luz de sus escritos". El texto que aquí se ofrece es una versión ampliada.
} 


\section{Jenofonte y su vínculo personal con Sócrates}

En cuanto a la forma en que se conocieron, Diógenes Laercio señala lo siguiente:

Dicen que, al encontrarlo en un callejón, Sócrates le extendió su bastón y le impidió pasar, preguntándole en dónde se vendería cada uno de los víveres; y luego de responderle, de nuevo le preguntó dónde se vuelven los hombres bellos y buenos. Y dado que [Jenofonte] no supo, [el filósofo le] dijo, "pues ven y aprende". Desde entonces fue discípulo de Sócrates. También fue el primero que puso por escrito y entregó a los hombres lo que se decía, al redactar sus Memorables. ${ }^{1}$

No existen datos precisos de cuánto tiempo se trataron ambos personajes, sólo hay conjeturas. Según Luccioni, se frecuentaron dos o tres años, ya que, durante la última etapa de la Guerra del Peloponeso, Jenofonte debió servir en la armada al igual que todos los atenienses de su edad y, después, tras la capitulación de Atenas en el 404 a. C., se enroló como caballero bajo los Treinta Tiranos. De manera que fue a partir del 403 a. C., una vez restablecida la democracia, cuando pudo escuchar tranquilamente a Sócrates. ${ }^{2}$ A pesar del corto tiempo, la convivencia de dos o tres años bastó para dejar su impronta en un espíritu inteligente y ávido de instrucción, como lo era el de Jenofonte. ${ }^{3}$

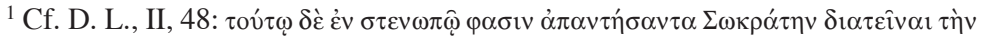

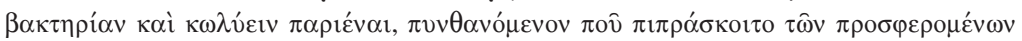

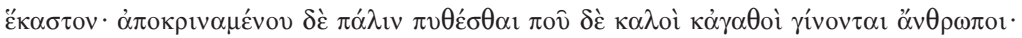

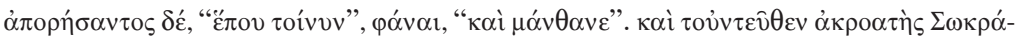

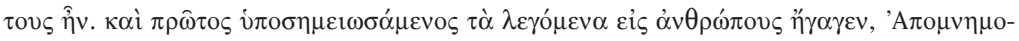



${ }^{2}$ Según García Gual, encontró a Sócrates en Atenas (hacia el 410 a. C.) y oyó con avidez juvenil las discusiones entre éste y los sofistas y los discípulos de otros ilustres pensadores (cf. su introducción en Jenofonte, Anábasis, p. 14).

${ }^{3}$ Cf. Luccioni, Xénophon et le socratisme, p. 4.
} 
En la Anábasis, él mismo relata de qué manera Sócrates le aconsejó que, antes de decidir su adhesión a la empresa de Ciro el Joven, fuera a Delfos. ${ }^{4}$ García Bacca sostiene que cuando Jenofonte retornó a Atenas, luego de la expedición de los Diez Mil, no encontró a su maestro; pues había sido condenado a muerte y ya había bebido la cicuta. ${ }^{5}$

\section{¿Jenofonte socrático?}

Conviene señalar que desde antaño ha habido controversia en torno a si en verdad este autor formó parte del círculo socrático, pues no se sabe con certeza qué tan estrecho fue su contacto personal con Sócrates; incluso hay quienes, como Humbert, afirman que Jenofonte únicamente ofrece informes de segunda mano acerca de la cuestión socrática. ${ }^{6}$

Entre los autores antiguos que se refieren a Jenofonte como un filósofo socrático están: Cicerón (Brutus, 292), Dioniso de Halicarnaso (Comp., 10), Quintiliano (10, I, 75, 82-83), Tácito (Dial. Orat., 31, 6), Longino (4, 4), además de Diógenes Laercio (II, 64), quien incluye la vida de Jenofonte exactamente después de la de Sócrates. Pomeroy aclara que en Alemania hasta mediados del siglo XVIII tanto el testimonio de Platón como el de Jenofonte gozaban de igual prestigio. Fue más tarde, cuando Brucker sostuvo que las Memorables daban una idea más precisa de Sócrates, que F. Schleiermacher rechazó dicha postura y se inclinó por Platón, al argumentar que el jefe de los Diez Mil no fue un filósofo y que quizá no tuvo la capacidad de comprender a su maestro. Como señala Pomeroy, a partir de esta polémica las opiniones se dividen. ${ }^{7}$

\footnotetext{
${ }^{4}$ Cf. An., III, 1, 5-8.

${ }^{5}$ Cf. Jenofonte, Socráticas. Economía. Ciropedia, pp. XI-XIII. Sentía una gran afinidad con Sócrates y la muerte de éste le afectó profundamente (cf. Salay, Socrates the whipping post: Xenophon's portrayal of Socrates as a rebuke of Athenian Society, p. XIII).

${ }^{6} \mathrm{Cf}$. Socrate et les petits socratiques, p. 7.

${ }^{7}$ Cf. Xenophon, Oeconomicus. A social and Historical Commentary, pp. 23-26.
} 
Para Souto Delibes, el abandono moderno contrasta mucho con el aprecio en que se tuvo a Jenofonte en el pasado. ${ }^{8}$ Entre las principales causas que el estudioso da para entender la depreciación de este autor ateniense están las siguientes:

desde los primeros tiempos, la obra de Jenofonte se utilizó para aprender griego en las escuelas por la limpieza y sencillez de su estilo. Esto, sin duda, le quitó parte de la categoría de que gozan otros escritores más difíciles. Por otro lado, la obra de Jenofonte abarca aspectos tan diversos [...] que no puede ser abarcada por un solo especialista. La necesaria fragmentación para su estudio, conlleva que Jenofonte pierda ante la atenta mirada de los eruditos uno de sus mayores méritos, el haber logrado escribir con dignidad en muy diferentes géneros literarios. Esta amplitud de miras también perjudica a Jenofonte cuando se compara una de sus obras con las de otros expertos de la época que sólo concentraron sus esfuerzos en un género literario. Nos estamos refiriendo, naturalmente, a Tucídides por el lado de la Historia y a Platón por el de la Filosofía. ${ }^{9}$

Para retomar el punto de si en verdad el jefe de los Diez Mil merece ser calificado como un auténtico socrático, es preciso traer a colación lo que opinan varios estudiosos modernos. De acuerdo con Luccioni, Jenofonte amerita ser considerado un socrático por dos razones primordiales: primero, porque habla de Sócrates y lo convierte en personaje de varios de sus diálogos $;^{10}$ y segundo, porque es heredero de la doctrina socrática, ya que a través de sus escritos, incluso en los que no aparece el nombre de Sócrates, se vislumbran claramente las ideas de su maestro, a las que él les da un matiz sumamente práctico. $^{11}$

\footnotetext{
${ }^{8}$ Souto, La figura de Sócrates en Jenofonte, p. 2.

${ }^{9}$ Ibid., pp. 3-4.

${ }^{10}$ Compuso cuatro obras directamente relacionadas con Sócrates: Económico, Simposio, Apología y Memorables.

${ }^{11}$ Cf. Luccioni, Xénophon et le socratisme, p. 165.
} 
Desde el punto de vista del estudioso francés, Jenofonte es un socrático porque su testimonio concuerda con el de Platón, ${ }^{12}$ pues uno encuentra en sus obras las mismas ideas. Al respecto, viene al caso aclarar que - debido al carácter ágrafo de la doctrina de Sócrates - cada uno de sus discípulos manifiesta su propio pensamiento, preserva y desarrolla su propia originalidad. A esto se debe que desde antaño este filósofo fuera uno y múltiple, ya que a partir de su pensamiento se derivaron doctrinas muy distintas. Jaeger sostiene esta idea al afirmar que

Sócrates pertenece al siglo anterior, pero aquí se le considera como la figura que marca el viraje intelectual de los comienzos del período de Platón. La influencia real de Sócrates empezó a revelarse de un modo póstumo cuando los hombres del siglo IV comenzaron a discutir en torno a su carácter e importancia; todo lo que conocemos de él [...] es un reflejo literario de esta influencia que ejerció sobre sus contemporáneos más jóvenes y que se convirtió en fama después de su muerte. ${ }^{13}$

Así se explica que Platón y Jenofonte, aunque hablan del mismo personaje, conservan su personalidad propia. ${ }^{14}$ De este modo, lo que Jenofonte ofrece es una interpretación del pensamiento de su maestro, cuya doctrina del esfuerzo del espíritu humano se proponía que cada quien se conociera mejor y se comprendiera mejor, que analizara mejor sus propias ideas.

Luccioni reconoce que aunque Jenofonte no siempre comprendió o retuvo lo más elevado del pensamiento de Sócra-

\footnotetext{
${ }^{12}$ Platón y Jenofonte coinciden en varias cosas: ambos son atenienses, nacen hacia el mismo año, conocen a Sócrates en persona e intentan defender su memoria. Además, cada uno escribió una Apología y un Simposio; pero en cuanto a temperamento y talento intelectual un abismo los separa (cf. Gómez-Lobo, La ética de Sócrates, p. 13). Para Deleito, en comparación con Platón, “Jenofonte, más humilde e impersonal, sólo aspiró a ser el espejo donde se proyectasen ante la admiración de la posteridad aquella vida y aquella doctrina por él veneradas" (cf. su nota preliminar en Jenofonte, La vida y las doctrinas de Sócrates, p. VII).

${ }^{13}$ Cf. Jaeger, Paideia, II, p. XI.

${ }^{14}$ Cf. Luccioni, Xénophon et le socratisme, p. 167.
} 
tes - pues él mismo llegó a deformarlo, sea a propósito, sea involuntariamente - , en gran medida

contribuyó a difundir su imagen, a volverlo popular ante la posteridad, por así decirlo, y también a difundir varias de sus ideas más importantes, las que eran accesibles a las personas honestas, a quienes podían proporcionar varios principios de conducta o elementos morales. En suma, Jenofonte ha sido el intermediario entre el pensamiento de Sócrates y el gran público. Su labor socrática consistió en divulgar, ${ }^{15}$

y esto es razón suficiente para que tenga un lugar seguro en la historia de las ideas del s. IV a. C.

En opinión de Luccioni, si el hijo de Grilo recuerda uno u otro precepto de Sócrates lo hace precisamente porque estaba de acuerdo con ellos y porque le constaba que eran válidos. ${ }^{16}$ Según este autor, su socratismo corresponde a un hombre siempre atento al beneficio que podía obtener de la aplicación de las ideas a ciertas áreas de la vida cotidiana; pues, conforme a su propia naturaleza, Jenofonte no separaba el conocimiento y la aplicación, la sabiduría teórica y la sabiduría práctica. En este sentido, la relación con Sócrates le resultó provechosa y vio su filosofía como una doctrina práctica y digna de ejercicio. $^{17}$

Al mismo Jenofonte le agradaba ser útil, por eso su socratismo refleja su personalidad práctica; es el socratismo propio de un militar, de un terrateniente, de un economista. Su obra

\footnotetext{
${ }^{15}$ Cf. Luccioni, Xénophon et le socratisme, p. 172.

${ }^{16}$ Cf. ibid., p. 168. Más adelante, el estudioso observa con justicia que, si bien Jenofonte le debe a Sócrates la mayor parte de sus ideas morales, conservó para sí aquello acorde con su propia forma de pensar; añadiendo a las lecciones de su maestro lo que había aprendido gracias a su experiencia personal y también lo que otros individuos le habían transmitido, ya verificado o interpretado. Es aquí donde Jenofonte manifiesta su personalidad propia (cf. ibid., pp. 109 y 153).

${ }^{17}$ Cf. ibid., p. 168. Por mi parte, pienso que gracias al carácter práctico de la doctrina socrática, Jenofonte es un fiel adepto de Sócrates.
} 
es la de un autor que posee cierta cultura filosófica, porque ha sido educado por un gran filósofo. Recurre a la filosofía para que sea una ayuda en el manejo de los asuntos públicos y privados. ${ }^{18}$

Por su parte, García Bacca reconoce el testimonio de Jenofonte al afirmar que la imagen de Sócrates aportada por él es el único contrapeso para no ceñirse a la ofrecida tan seductoramente por Platón:

Que de disponer solamente de la de éste, todos creyéramos ya haber alcanzado la comprensión genuina y perfecta de aquel hombre extrañísimo fuera de toda casilla, átopos, como le llamaban los contemporáneos y nos lo ha conservado el mismo Platón. Pero al contraponer Platón y Jenofonte, dos testigos presenciales de los mismos sucesos, la oposición de las figuras del Sócrates platónico y del Sócrates jenofontiano resulta tan distinta y aun completa que el desconcierto que su oposición y diversidad ha causado en los lectores, intérpretes y críticos ha sido tal, tanto y tan incurable que hasta el día de hoy dura. ${ }^{19}$

Añade que, de acuerdo con Jenofonte, Sócrates era puro y simple hombre, encarnación de la norma helénica clásica del nada en demasía. Por el contrario, el Sócrates de Platón "parece más un dios disfrazado de mortal, de aquel tipo de dios peregrino que para tentar a los mortales, dice Platón en el Sofista y por boca de Sócrates - 216a, b-, aparece en fauna de filósofo". ${ }^{20}$

\footnotetext{
${ }^{18}$ Cf. Luccioni, Xénophon et le socratisme, p. 170. Al respecto, García Gual dice que "hay nostalgia en la evocación de las charlas con Sócrates, un maestro en virtud y en patriotismo, que atrajo al joven Jenofonte sin lograr hacer de él un filósofo" (cf. su introducción en Jenofonte, Anábasis, p. 12). En n. 6 agrega que "el socrático que escribe sus recuerdos a una distancia de muchos años es también el aventurero y el agricultor, y que reúne todas esas experiencias en su vejez reflexiva. Y eso da más valor a sus reflexiones" (cf. Jenofonte, Anábasis, pp. 12-13).

${ }^{19}$ Cf. el estudio preliminar de García Bacca en Jenofonte, Socráticas. Economía. Ciropedia, p. XIII.

${ }^{20}$ Ibid.
} 
Por su lado, Palacios Roa observa que a pesar de que Jenofonte era demasiado joven cuando conoció a Sócrates y no tuvo tiempo de entrar en su círculo de discípulos más allegados, logró comprender su pensamiento, convirtiéndolo en el detonante fundamental del desarrollo de sus ideas y de toda su doctrina filosófica. De manera que, pese a sus aparentes limitaciones que impedían o mermaban su comprensión total de las doctrinas socráticas, su vínculo con su maestro fue muy fuerte y duradero. ${ }^{21}$ Según este estudioso, entre los motivos que atrajeron al joven Jenofonte, miembro de la aristocracia terrateniente, hacia la extravagante figura de Sócrates están su entereza moral y, sobre todo, su valor militar, además de su particular método de poner las creencias más habituales en tela de juicio, generando una especie de provocación, contestación y protesta hacia las instituciones. Desde esta perspectiva, Jenofonte formaba parte de aquellos círculos de jóvenes que consideraban a Sócrates como un modelo a seguir, pero confundían y entremezclaban sus inclinaciones individuales y su antipatía por la democracia con el intento de renovación espiritual mucho más profundo y duradero que su maestro trataba de proporcionar. $^{22}$

De acuerdo con Jaeger, Jenofonte, al igual que tantos muchachos de su generación, se sintió atraído por Sócrates y, aunque "no llegó a contarse entre sus discípulos en sentido estricto, fue tan profunda la impresión que aquel hombre dejó en él, que a su vuelta del servicio militar en el ejército de Ciro elevó al querido maestro, en sus obras, más de un monumento perdurable". ${ }^{23}$

Para Lesky, Jenofonte "no fue discípulo de Sócrates a la manera de aquellos otros que durante toda su vida no se apar-

\footnotetext{
${ }^{21}$ Cf. Palacios Roa, "Jenofonte: el hombre, el estratega y su obra", Limes, 19, 2007, p. 167. Anderson sostiene este mismo punto de vista (cf. Xenophon, p. 28).

${ }^{22}$ Cf. Palacios Roa, art. cit., p. 168.

${ }^{23}$ Jaeger, Paideia, III, p. 201, y II, p. 21.
} 
taron de la filosofía; pero las impresiones que recibió entonces perduraron, sin convertirse, por supuesto, en impulsos orientadores de su vida". ${ }^{24}$

Humbert señala que, si bien Jenofonte no fue capaz de comprender la profundidad del pensamiento de Sócrates, a quien frecuentó poco tiempo, su testimonio es muy valioso - aunque sea indirecto-; pues muestra algunos aspectos familiares, cotidianos, de la actividad moral de su maestro, que Platón omitió por considerarlos insignificantes. ${ }^{25}$

En torno a esta polémica, Souto reconoce que tal vez Jenofonte no formó parte del círculo socrático, pero se mantuvo en contacto con él. ${ }^{26}$ García Gual afirma que Jenofonte recordó siempre las nobles enseñanzas de Sócrates. ${ }^{27}$

Por su parte, Galino sostiene que este autor ateniense fue uno de los discípulos más fieles de Sócrates, ${ }^{28}$ quien, al igual que su maestro, procura la educación moral y civil de sus conciudadanos, y en sus obras intenta formarlos en la justicia y el bien. Considera que es un socrático, cuyo temperamento activo y aventurero define su socratismo. Así mismo, menciona que, a diferencia de Platón, Jenofonte posee un espíritu práctico, "no es un teórico de la ciencia pura, sino de la vida práctica". 29

Hasta aquí en cuanto al juicio de algunos autores modernos.

\section{Sócrates según Jenofonte}

Aunque Jenofonte compuso cuatro escritos directamente relacionados con Sócrates: Económico, Simposio, Apología y

\footnotetext{
${ }^{24}$ Lesky, Historia de la literatura griega, p. 646.

${ }^{25} \mathrm{Cf}$. Humbert, Socrate et les petits socratiques, p. 7.

${ }^{26}$ Cf. Souto, La figura de Sócrates en Jenofonte, p. 12.

${ }^{27}$ Cf. su introducción en Jenofonte, Anábasis, p. 9.

${ }^{28}$ Cf. Galino, Historia de la educación. Edades antigua y media, p. 193.

${ }^{29}$ Cf. ibid., p. 129.
} 
Memorables, ${ }^{30}$ para esta sección tomo como base la última obra, debido a que en ella proporciona una imagen más amplia de su maestro, y la complemento con los datos que este autor disemina en las otras obras socráticas. A mi juicio, los aspectos más relevantes acerca de la enigmática personalidad de Sócrates son los siguientes:

- En términos generales, es en el Simposio donde da la descripción física de su maestro: tenía ojos saltones, nariz chata, boca grande y labios gruesos, parecido a los silenos. ${ }^{31}$

- A grandes rasgos, Jenofonte lo describe como el más austero para los placeres del amor y de la comida, durísimo frente al frío y al calor, y todas las fatigas, estaba educado de tal manera que al tener pocas necesidades una modesta fortuna le bastaba para satisfacerlas. ${ }^{32}$ Jamás descuidó su cuerpo, reprobaba comer en demasía, no era afectado ni presumido en su vestimenta ni en su calzado, ni en su régimen de vida en ge-

\footnotetext{
${ }^{30}$ En torno a las fuentes usadas por Jenofonte para redactar esta obra, cf. Souto, La figura de Sócrates en Jenofonte, pp. 292-344.

${ }^{31}$ Cf. el diálogo sostenido entre Sócrates y Critobulo, donde el hijo de Sofronis-

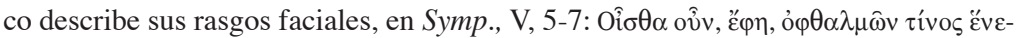

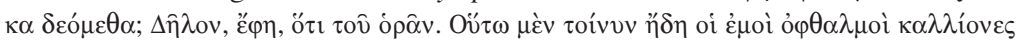

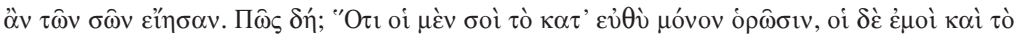

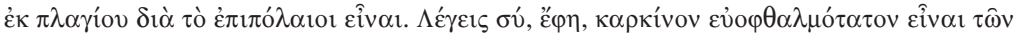

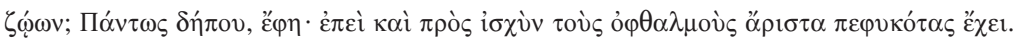

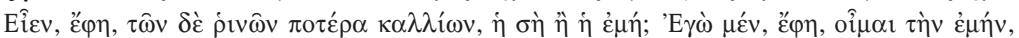

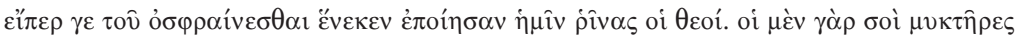

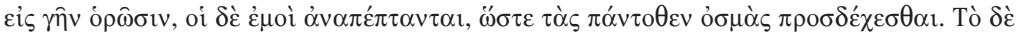

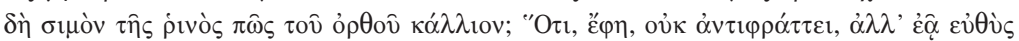

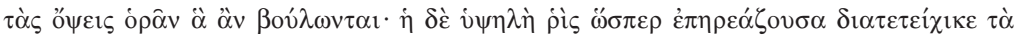

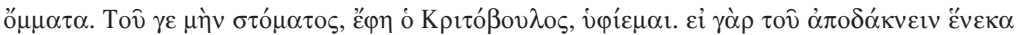

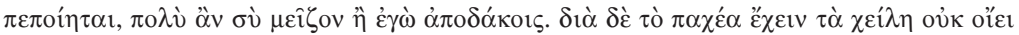

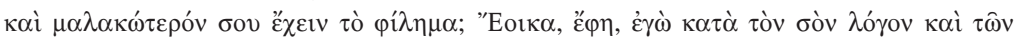

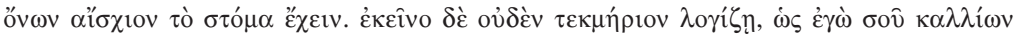

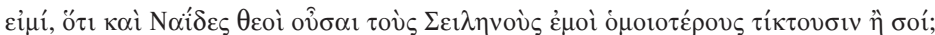

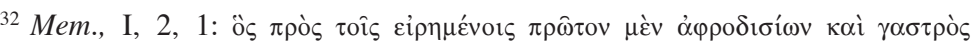

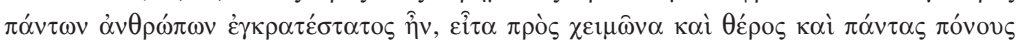

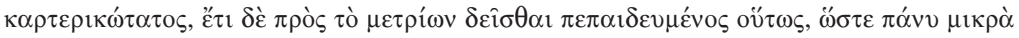

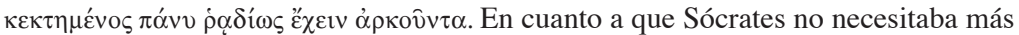
riquezas, cf. Oec., II, 2 y 4.
} 
neral, nunca fomentó la codicia en sus alumnos. ${ }^{33}$ Había educado su espíritu y su cuerpo de modo que podía vivir con confianza y seguridad, era muy frugal; en cuanto a la bebida, todo le resultaba agradable, ya que sólo bebía cuando tenía sed. ${ }^{34}$ Acerca de los placeres sexuales, recomendaba abstenerse de las personas bellas, porque suelen crear adicción. ${ }^{35}$ También insistía en que sus discípulos procuraran mantenerse sanos, al cuidar su dieta. ${ }^{36}$

En específico, Jenofonte menciona que

- Siempre conversaba sobre temas humanos, ${ }^{37}$ examinando qué es piadoso, qué es impío, qué es bello, qué es justo, qué es injusto, etc. ${ }^{38}$

- Siempre cuidó su cuerpo y reprendía a quienes no tomaban en cuenta este aspecto, ${ }^{39}$ pues desde su punto de vista

${ }^{33}$ Cf. Mem., I, 2, 4-5. Cf. también I, 6, 3, donde Antifonte llama a Sócrates un profesor de miseria, y en I, 6, 5-10, la respuesta de Sócrates, entre cuyos argumentos destaca que no necesitar nada es algo divino, y necesitar lo menos posible equivale a estar muy cerca de la divinidad.

${ }^{34}$ Cf. Mem., I, 3, 5-6.

${ }^{35}$ Cf. Mem., I, 3, 8 y 14. En otro pasaje Jenofonte afirma que Sócrates a menudo se enamoraba no tanto de un cuerpo bello, sino de un alma virtuosa (IV, 1, 2).

${ }^{36}$ Cf. Mem., IV, 7, 9. Según Salay, en Memorables Jenofonte pone de manifiesto que, al condenar a Sócrates, condenaron a muerte al único hombre que ejemplificaba todas las virtudes que los atenienses decían apreciar y, al hacerlo, demostraron que era falso su desprecio de los vicios, también se hizo evidente de manera implícita que gente criminal tenía el control de Atenas, personas esclavas de sus pasiones y de dudosa moral, quienes eliminaron al único ciudadano capaz de hacerles ver sus fallas éticas (cf. Socrates the whipping post: Xenophon's portrayal of Socrates as a rebuke of Athenian Society, pp. 71-72).

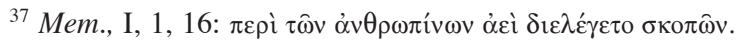

${ }^{38}$ Cf. Mem., I, 1, 16.

${ }^{39} \mathrm{Cf}$. Mem., I, 2, 4, y I, 6, 7. Al igual que su maestro, Jenofonte deplora que el estado ateniense descuide los ejercicios marciales, baste recordar el diálogo sostenido entre Sócrates y Pericles hijo, donde a través de este último el autor deja entrever su predilección por los hábitos espartanos: “¿cuándo respetarán los atenienses a los mayores como lo hacen los lacedemonios, ya que desprecian a los ancianos, empezando por sus padres, o cuándo se entrenarán físicamente de la misma manera, ellos que no sólo no se cuidan de su bienestar físico sino que 
era aconsejable practicar ejercicio para el adecuado robustecimiento físico. ${ }^{40}$

En Memorables, el filósofo pronuncia un largo discurso a través del cual hace hincapié en la importancia que tiene el ejercicio, ya que preocupado por la formación del ciudadano y a que, debido a sus vivencias en la guerra, había constatado en persona las ventajas de tener un cuerpo en buenas condiciones, entre sus argumentos destaca que en nada perjudica tener un cuerpo sano; mientras el mal estado físico puede provocar la pérdida de la memoria o manías que dañan el entendimiento, de manera que gracias al ejercicio se evitan los males ocasionados por el envejecimiento prematuro. ${ }^{41}$

En el Simposio en concreto, el filósofo subraya que con la danza se ejercita todo el cuerpo, lo cual es ideal para mantenerse en buenas condiciones y lograr el equilibrio corporal. ${ }^{42}$ Sócrates estaba muy interesado en el deporte y el ejercicio físico en general, ello lo hacía alabar a los espartanos, quienes debido a su duro entrenamiento eran considerados los mejores caudillos militares. ${ }^{43}$ El maestro de Jenofonte defendía el desarrollo integral del cuerpo y desdeñaba el desequilibrio físico. ${ }^{44}$

- Sócrates siempre respetó las leyes vigentes y se identificó con su patria, a la que nunca dejó; sin embargo, reconocía el buen funcionamiento de las instituciones espartanas, admiración recurrente en el pensamiento de sus alumnos. ${ }^{45}$ En torno

\footnotetext{
incluso se burlan de los que lo hacen?" (cf. Mem., III, 5, 15, sigo la traducción de Juan Zaragoza publicada en Gredos).

${ }^{40}$ Cf. Mem., I, 6, 7, y II, 1, 28. Cf. también Mem., IV, 7, 9. En palabras de Souto, "Sócrates prestó gran atención a la práctica del ejercicio y consideró la gimnasia como disciplina fundamental para la educación del ser humano" (cf. Souto, La figura de Sócrates en Jenofonte, p. 216). Cf. Mem., I, 2, 4; I, 6, 7, y IV, 7, 9.

${ }^{41}$ Cf. Mem., III, 12, 1-8.

${ }^{42}$ Cf. Symp., II, 16-17.

${ }^{43}$ Cf. Symp., VIII, 39.

${ }^{44}$ Cf. Symp., II, 17.

${ }^{45}$ Cf. Souto, La figura de Sócrates en Jenofonte, pp. 357-358.
} 
a la democracia, sostenía que era absurdo designar mediante un sorteo a los magistrados de la polis. ${ }^{46}$ En Memorables se hace evidente un Sócrates profundamente imbuido en la administración del Estado, lo cual se desprende a partir de sus diálogos con Nicomáquides y con otros personajes con quienes aborda la temática militar. ${ }^{47}$ El filósofo consideraba que su incidencia en la política no radicaba en su participación directa en dicho ámbito, sino en capacitar a la mayor cantidad posible de personas para que lo hicieran de forma adecuada. ${ }^{48}$

- Por lo que atañe a la piedad religiosa, en opinión de Souto, la acusación por impiedad

se refiere a no reconocer a los dioses el culto prescrito por la ley y no a un pensamiento heterodoxo con respecto a las creencias. La religión de la ciudad, carente de dogmas y libros sagrados, exenta de una casta sacerdotal dedicada a la vigilancia de éstos, no podía reconocer delitos de ateísmo o herejía. ${ }^{49}$

De acuerdo con esto, Sócrates no era el ateo que Meleto afirmaba, pero tampoco mostraba una religiosidad ortodoxa, porque su manera de entender la religión se salía de lo normal. Según dicho estudioso, el Sócrates jenofóntico es conocedor respetuoso de las leyes cultuales y parece respetarlas. ${ }^{50}$ Souto sostiene que a partir de un pasaje de la Anábasis (III, 1, 5-7), donde Sócrates le recomienda a Jenofonte que consulte el oráculo de Delfos, y al Simposio (II, 1), donde el maestro entona un peán a Apolo, es posible hallar testimonios de que respetaba las tradiciones atenienses tanto en lo público como en lo

${ }^{46}$ Cf. Mem., I, 2, 9. Según Souto, era característico de Sócrates su crítica a la democracia, a sus instituciones y a sus políticos, pues no ocultaba su simpatía por las instituciones dorias, en especial por Esparta y Creta (cf. Souto, La figura de Sócrates en Jenofonte, p. 81).

${ }^{47}$ Por sólo mencionar algunos ejemplos, cf. Mem., III, 1-5.

${ }^{48}$ Cf. Mem., I, 6, 15, también III, 6 y 7.

${ }^{49}$ Souto, La figura de Sócrates en Jenofonte, p. 83.

${ }^{50}$ Cf. Apol., 11. 
privado. Con base en lo anterior, Souto concluye que, pese a su extraña concepción religiosa, Sócrates nunca ofendió el culto. ${ }^{51}$

De la lectura de Memorables se desprende que Sócrates seguía los preceptos legales del culto, pues tanto en su casa como en los altares públicos realizaba sacrificios ${ }^{52}$ y recomendaba a los demás que hicieran lo mismo. ${ }^{53}$ En sus súplicas no pedía cosas superficiales, ${ }^{54}$ y honraba a los dioses con modestas ofrendas, con aquello que su posición económica le permitía. ${ }^{55}$ Acataba las indicaciones de la Pitia ${ }^{56}$ y del Oráculo de Delfos y, cuando no sabía cómo orientar a sus discípulos, los enviaba a que consultaran al dios de la adivinación. ${ }^{57}$ Sócrates creía que los dioses lo saben todo, lo que se dice, lo que se hace, y lo que se debate en secreto, que están presentes en todas partes y que dan señales a los hombres en todos los problemas humanos, por eso tanto en público como en privado hay que evitar las acciones impías, injustas y vergonzosas. ${ }^{58}$ Según Jenofonte nadie vio nunca ni oyó a su maestro hacer o decir nada impío o ilícito. ${ }^{59}$

\footnotetext{
${ }^{51}$ Cf. Souto, La figura de Sócrates en Jenofonte, pp. 89-90.

${ }^{52}$ Cf. Mem., I, 1, 2.

${ }^{53}$ Cf. Mem., I, 1, 4, y IV, 3, 2. En Oec., VI, 1, Critobulo afirma que Sócrates
} le recomienda que antes de cualquier empresa debe encomendarse a las deidades, tanto en labores de paz como en las bélicas.

${ }^{54}$ Cf. Mem., I, 3, 2.

${ }^{55}$ Cf. Mem., I, 3, 3. Según Jenofonte, Sócrates pensaba que a los dioses les agradaban más las ofrendas de las personas más piadosas. Cf. también IV, 3, 16-18.

${ }^{56}$ Cf. Mem., I, 3, 1.

${ }^{57}$ Cf. Mem., I, 1, 6 y 9; IV, 3, 16-17, y 7, 10. Cf. también An., III, 1, 5-7, donde Sócrates le aconseja a Jenofonte que antes de alistarse con Ciro el Joven consulte el oráculo.

${ }^{58}$ Cf. Mem., I, 4, 19-20. Y "hablando así no sólo enseñaba a sus discípulos a apartarse de acciones impías, injustas y vergonzosas cuando estaban a la vista del público, sino también cuando estaban solos, porque estaban efectivamente convencidos de que nada de cuanto hicieran pasaría inadvertido a los dioses" (cf. ibid., I, 4, 19, sigo la traducción de Gredos).

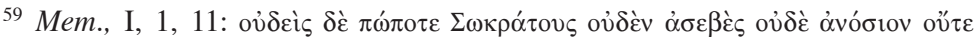

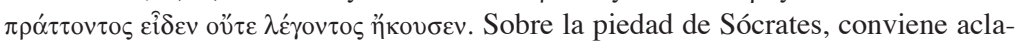


- Sócrates era justo. En el ámbito privado trataba a todos según lo estipulado en la ley, en lo público, obedecía a quienes detentaban el poder actuando siempre de acuerdo con las leyes, tanto en lo civil como en lo militar. ${ }^{60}$ Sin embargo, no dudaba en rechazar lo que le parecía injusto. Baste mencionar que en una asamblea, aún siendo presidente del Pritaneo, se opuso a que se efectuara una votación ilegal. ${ }^{61}$ Es más, voluntariamente prefirió morir obedeciendo la ley en vez de huir o implorar el perdón. ${ }^{62}$ Nunca dio falso testimonio ni denunció a nadie, ni fomentó discordias, para él no incurrir en la injusticia es muestra de ser justo. ${ }^{63}$ De acuerdo con el filósofo, una persona justa, que acata las leyes, tiene garantizados los mayores honores, la victoria en los tribunales, y los demás confían en ella para que custodie a sus hijos y sus bienes; pues lo legal y lo justo son lo mismo. No obstante, reconocía que también existen leyes no escritas, establecidas por los dioses y de igual modo es preciso obedecerlas. ${ }^{64}$ En la Apología, el propio Sócrates afirma que a lo largo de toda su vida nunca cometió ninguna acción injusta, ésa es su mejor defensa. ${ }^{65}$

\footnotetext{
rar que para los antiguos griegos la piedad implicaba una actitud decorosa ante la muerte, de parientes, de ancestros, y de todos los miembros de la polis (cf. Colaiaco, Socrates against Athens, p. 118). Alegre observa que "Sócrates era profundamente religioso, pero portador de una religión extraña a los griegos; se trataba de una religión cruce de trascendencia superadora de la polis, de la religión del Estado. Sócrates se cuidaba mucho de cumplir con todos los preceptos religiosos; fue en vano, pues la gente se percató de lo atípico de la nueva religión..., Sócrates era incómodo para todos, oligarcas y progresistas" (cf. Alegre, La sofística y Sócrates. Ascenso y caída de la polis, p. 100).

${ }^{60}$ Cf. Mem., IV, 4, 1.

${ }^{61}$ Cf. Mem., I, 1, 18, y IV, 4, 3.

${ }^{62}$ Cf. Mem., IV, 4, 4.

${ }^{63}$ Cf. Mem., IV, 4, 10-11.

${ }^{64}$ Cf. Mem., IV, 4, 17-19. En cuanto al hecho de que Sócrates cumplía con los ritos establecidos, cf. Mem., I, 1, 2. Acerca de que los dioses indican lo oculto, Mem., I, 1, 9.

${ }^{65}$ Cf. Apol., 3. Según Sócrates las acciones son más convincentes que las palabras (Mem., IV, 4, 10), ello explica el hecho de que, cuando Hermógenes le acon-
} 


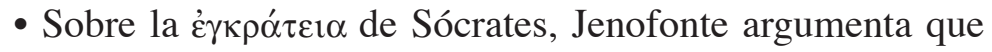
su maestro fue capaz de vencerse a sí mismo y sólo así pudo enseñarles esto a los demás, al inculcarles el deseo de ejercitarse para controlarse a sí mismos ante la comida y la bebida, la lujuria y el sueño, el frío, el calor y el cansancio. ${ }^{66}$ Sócrates dominaba sus pasiones. ${ }^{67}$ El filósofo pensaba que el autodominio era una cualidad indispensable para todo aquel que deseara realizar una acción noble, por eso era el primero en practicarla y enseñarla. ${ }^{68}$ Sostenía que quien no se controla a sí mismo renuncia de manera tácita a comportarse libre e inteligentemente. ${ }^{69}$ Con respecto a esto, Sócrates consideraba que el verdadero placer se obtiene luego de haber anhelado durante mucho tiempo algo y haber soportado estar sin ello, gracias a dicha actitud se disfruta más comer, beber, tener encuentros amorosos, dormir, etcétera. ${ }^{70}$ Por eso mismo promovía beber con moderación: le parecía correcto beber porque el vino adormece las penas y despierta lo placentero, ${ }^{71}$ pero se inclinaba a favor de moderarse en el beber, para que no se entorpezcan ni los sentidos ni el entendimiento, ${ }^{72}$ ni se arruine la convivencia a causa de la ebriedad. ${ }^{73}$

Desde su punto de vista, quien domina sus pasiones disfruta aprender cosas provechosas para sí mismo y para los demás, y únicamente la persona que se domina es capaz de elegir lo mejor y abstenerse de lo peor. ${ }^{74}$

\footnotetext{
seja preparar su defensa, el maestro de Jenofonte con toda entereza le contesta que toda su vida la dedicó a ello (cf. Mem., IV, 8, 4).

${ }^{66}$ Cf. Mem., I, 5, 1 y 6, así como II, 1, 1. Para una descripción más detallada de

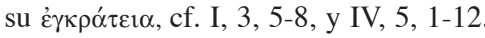

${ }^{67}$ Cf. Apol., 16.

${ }^{68} \mathrm{Cf}$. Mem., IV, 5, 1.

${ }^{69}$ Cf. Mem., IV, 5, 3-6. En Oec., I, 22, Sócrates menciona algunas consecuencias de dejarse dominar por las pasiones.

${ }^{70}$ Cf. Mem., IV, 5, 8-9. Cf. también I, 3, 15, y II, 1, 33.

${ }^{71}$ Cf. Symp., II, 24.

${ }^{72}$ Cf. Symp., II, 25-26.

${ }^{73}$ Cf. Symp., VI, 1.

${ }^{74}$ Cf. Mem., IV, 5, 10-11.
} 
- El Sócrates jenofóntico le daba mucha importancia a la palabra, instrumento indispensable para transmitir la experiencia propia, para educar y para persuadir, ${ }^{75}$ pues

cuanto hemos aprendido por costumbre, las cosas más bellas gracias a las cuales sabemos vivir, todo lo hemos aprendido por medio de la palabra, y si alguien adquiere algún otro bello conocimiento lo aprende por medio de ella, y los mejores maestros son los que más la utilizan, y quienes más saben de los temas más serios son los que saben hablar más bellamente. ${ }^{76}$

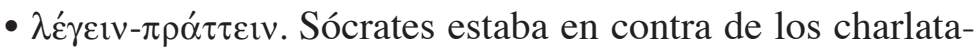
nes, de los improvisados y de los ineptos, creía en la necesidad de los conocimientos técnicos, en la competencia. ${ }^{77}$ Para él, fingir que se era experto en algo equivalía a exponerse a ser cubierto de oprobio y a causar daño a quienes ingenuamente confían en uno; ya que las falsas apariencias resultan peligrosas y dañinas. A propósito menciona el terrible mal que ocasiona dejar las cosas en manos de un piloto o un general incompetentes, pues sus malas decisiones resultan perjudicia-

\footnotetext{
${ }^{75}$ Cf. Salomone, "Letteratura, tradizione e novità tattico-strategique nello Hipparchikos di Senofonte", p. 199. Para confirmar su postura acerca de que la persuasión es más efectiva que la violencia, cf. Mem., I, 2, 10-11: "Yo, en cambio, opino que los que practican la prudencia y se consideran capaces de dar enseñanzas útiles a los ciudadanos son los que resultan menos violentos, porque saben que las enemistades y los peligros son propios de la violencia, mientras que con la persuasión se consiguen las mismas cosas sin peligro y con amistad. Los violentados, en efecto, nos odian como si fuéramos ladrones, mientras que los persuadidos sienten estima como si se les hubiera hecho un favor. Por consiguiente, emplear la violencia no es propio de quienes practican la prudencia, sino de quienes poseen la fuerza sin la razón. Además, el que se arriesga a la violencia necesita muchos valedores, mientras que quien puede persuadir no necesita ninguno, pues él solo cree que es capaz de convencer" (sigo la traducción de Gredos).

${ }^{76}$ Mem., III, 3, 11.

${ }^{77}$ La convicción de que para ocupar un cargo importante, como el de estratego o hiparco, sea indispensable el conjunto de una serie de cualidades, pero sobre todo la competencia, es un concepto propio de la enseñanza socrática (cf. Senofonte, Ipparchico. Manuale per il comandante di cavalleria, p. XXIX).
} 
les para todos. ${ }^{78}$ Además, se obedece de buen grado a personas más competentes, porque se juzga que ellas saben lo que es bueno para todos. Así, se convierte en un principio aplicado al arte militar y al arte político. ${ }^{79}$ Aclara que la sabiduría es el único fundamento posible de la autoridad y de la virtud política. ${ }^{80}$

- Valoraba mucho tener buenos amigos. ${ }^{81}$ Sócrates consideraba a la amistad como el don más preciado, por ello, en vez de verla con desdén, hay que cultivarla. ${ }^{82}$ En primer lugar procuraba elevar moralmente a sus amistades, ${ }^{83}$ pero no sólo le interesaba contar con buenos amigos, sino, incluso, presentarlos entre sí para que juntos se esforzaran por llegar a ser virtuosos. ${ }^{84}$ Dentro de sus reflexiones sobresale que "para adquirir amigos buenos, ha de ser bueno también uno mismo". ${ }^{85}$ En otra parte añade que únicamente mediante regalos se puede ganar uno a los hombres ruines, mientras a los varones bellos y buenos basta con tratarlos de manera amigable. ${ }^{86}$

${ }^{78}$ Cf. Mem., I, 7, 2-5. Acerca del piloto y del general ineptos, cf. II, 6, 38-39.

${ }^{79}$ Cf. Luccioni, Xénophon et le socratisme, p. 92. Acerca de la competencia, cf. Mem., III, 1, 2-3, y III, 4, 6, también III, 3, 9.

${ }^{80} \mathrm{Cf}$. Mem., III, 9, 10-12.

${ }^{81}$ Cf. Mem., I, 6, 14; II, 4; II, 5; II, 6; II, 9 y 10. Como observa Jaeger, la nueva cotización de la amistad es sintomática de la época de la guerra. Esto se debe a la descomposición interior de la sociedad y de todas las relaciones humanas, incluso de la familia, a consecuencia de la disgregación política cada vez más profunda y la acción de los sicofantes; todo esto propició que el individuo aislado se sintiera inseguro (cf. Jaeger, Paideia, II, pp. 67-68).

${ }^{82}$ Cf. Mem., I, 2, 7-8 y 14, así como II, 4, 5-7. A parte de un buen amigo, no hay nadie tan útil, nadie tan leal y constante, benéfico en todos los sentidos (cf. II, 4, 6). Ver también I, 2, 7. Cf. Oec., I, 14.

${ }^{83}$ Sócrates considera que ésta es la primera tarea del gobernante (cf. Rodríguez Adrados, Ilustración y política en la Grecia Clásica, p. 499, y Mem., I, 2, 3).

${ }^{84}$ Cf. Mem., I, 6, 14; II, 4-6.

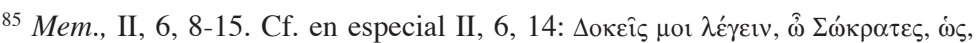

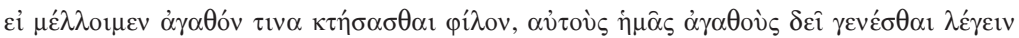

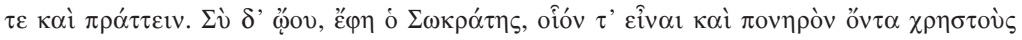

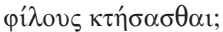

${ }^{86}$ Mem., II, 3, 16. 
- Sócrates incluía a la gratitud entre las principales características del hombre virtuoso. ${ }^{87}$ Para este sabio, la ingratitud es equivalente a la injusticia, ${ }^{88}$ desde esta perspectiva el no cuidar a los padres también denotaba un acto que además de ingrato resultaba injusto, por ello era tan penado entre los atenienses, al grado de que se castigaba con la atimía ${ }^{89}$ En su opinión, una persona ingrata no puede ser un buen amigo. ${ }^{90}$

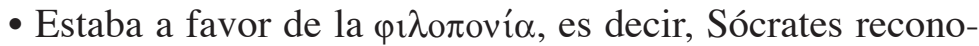
cía el valor del esfuerzo como forma de alcanzar la virtud. ${ }^{91}$ Afirmaba que quienes voluntariamente deciden soportar penas con tal de ser mejores y útiles a sus amigos y a su patria están satisfechos de sí mismos y son dignos de alabanza. ${ }^{92} \mathrm{El}$ filósofo destaca la virtud de soportar voluntariamente las penalidades, lo cual carece de mérito si se hace por obligación. Tras su disertación acerca de los sufrimientos voluntarios y los involuntarios, Jenofonte introduce el mito de Heracles en la encrucijada. ${ }^{93}$

- Censuraba la ociosidad y la negligencia, sostenía que gra-

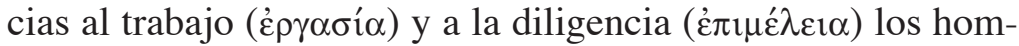
bres aprenden lo que les conviene, recuerdan lo que aprenden, se mantienen sanos y fuertes, adquieren y conservan lo que les es útil. ${ }^{94}$ Desde su punto de vista, debido a que los seres humanos se ocupan de cosas útiles son más sensatos y justos. ${ }^{95}$

\footnotetext{
${ }^{87}$ Cf. en específico Mem., II, 10, 3.

${ }^{88}$ Cf. Mem., II, 2, 2-3.

${ }^{89}$ Cf. Mem., II, 2, 13-14.

${ }^{90}$ Cf. Mem., IV, 4, 24.

${ }^{91}$ Cf. Mem., I, 2, 19-23. Cf. Oec., XI, 13.

${ }^{92} \mathrm{Cf} . \mathrm{Mem}$., II, 1, 18-19.

${ }^{93}$ Cf. Mem., II, 1, 18-34. Cabe señalar que Jenofonte también fue discípulo del sofista Pródico de Ceos, quien, entre otras cosas, sostenía que los dioses no conceden nunca a los mortales ningún verdadero bien sin esfuerzo, para demostrarlo contaba el mito acerca de la elección de Heracles.

${ }^{94}$ Cf. Mem., II, 7, 7.

${ }^{95}$ Cf. Mem., II, 7, 8.
} 
Se mostraba respetuoso de todo trabajo honrado. ${ }^{96}$ Según él, los hombres que invierten su tiempo en algo intrascendente, en lugar de hacer cosas de mayor provecho, están de ociosos. Consideraba la inactividad como dañina y perjudicial para el ser humano. ${ }^{97}$

- Recomendaba que sus discípulos se dedicaran a la agricultura. El Sócrates jenofóntico enfatiza que para el hombre de bien la agricultura constituye la actividad y el saber más importantes, porque el cultivo de la tierra proporciona el sustento a los seres humanos. Entre otras ventajas, quien practica la agricultura mantiene su cuerpo en buenas condiciones y puede disfrutar de más tiempo libre para destinarlo a los amigos y a la polis, de igual modo fomenta el valor. ${ }^{98}$ En cuanto a esto último, el maestro de Jenofonte destaca que

los que se dedican a la agricultura, que reciben una educación enérgicamente viril, éstos, bien entrenados de cuerpo y espíritu, están en condiciones, si la divinidad no se lo impide, de invadir el país de los sitiadores y apoderarse de lo que necesiten para alimentarse. ${ }^{99}$

En términos generales, el Sócrates de Jenofonte reconoce que vivir de la labor agrícola es lo más noble, lo mejor y lo más grato. ${ }^{100}$

- Prefería la muerte antes que la vejez. ${ }^{101}$ Desde esta perspectiva, la decadencia y las miserias de la senectud son una

\footnotetext{
${ }^{96}$ En Mem., II, 7, 10, Sócrates sostiene categóricamente que es preferible la muerte antes que trabajar en algo vergonzoso.

${ }^{97}$ Cf. Mem., I, 2, 57. Cf. Oec., I, 19-20.

${ }^{98}$ Cf. Oec., VI, 8-10. Para mayores detalles acerca del encomio que el filósofo hace de la agricultura, cf. ibid., IV, 4-V, 17.

${ }^{99}$ Oec., V, 13 (sigo la traducción de Gredos).

${ }^{100}$ Cf. Oec., VI, 11. En el diálogo que sostiene con Sócrates, Iscómaco afirma que la agricultura hace más nobles de corazón a quienes se dedican a ella (cf. ibid., $\mathrm{XV}, 12)$.

${ }^{101}$ Cf. Apol., 1.
} 
constante en toda la Apología ${ }^{102}$ de Jenofonte; ya que la decrepitud es la causa principal de la decadencia de los sentidos y la mente, es algo vergonzoso y molesto, ${ }^{103}$ es la parte más miserable de la vida, ${ }^{104}$ edad en la que confluyen todas las amarguras y se escapan todas las alegrías. ${ }^{105}$ Souto admite como posible que Sócrates pronunciara los argumentos que Jenofonte reproduce, y que viera lo conveniente de su muerte debido a su avanzada edad, pero el jefe de los Diez Mil exagera la importancia llegando a justificar así la muerte de su maestro. ${ }^{106}$

- Acerca de su labor educativa, Sócrates nunca se asumió a sí mismo como maestro, pero con su manera de ser fomentó en sus discípulos la esperanza de que, si lo imitaban, llegarían a ser como él. ${ }^{107}$ No cobraba, debido a su convicción de que así aseguraba su libertad y a que creía que su mayor ganancia era obtener un buen amigo. ${ }^{108}$ De acuerdo con este filósofo, quienes aceptaban una paga se vendían, pues se comprometían a conversar con los que les daban dinero. ${ }^{109}$

\footnotetext{
${ }^{102}$ Acerca de esta obra, Souto sostiene que con probabilidad Jenofonte la escribió en Escilute, y tomó como base la literatura socrática que tuvo a la mano, entre las fuentes remite a Hermógenes, Antístenes y Platón, es por demás interesante el tratamiento que el estudioso da a esta parte donde cuestiona si se trata de "un Jenofonte plagiario de Platón o un Platón lector y copista de Jenofonte" (Souto, La figura de Sócrates en Jenofonte, p. 48). Para mayores detalles sobre las fuentes a las que recurrió Jenofonte para componer la Apología, cf. Souto, ibid., pp. 25-59.

${ }^{103}$ Cf. Apol., 6-7.

104 Cf. Apol., 32.

105 Cf. Apol., 8.

${ }^{106}$ Cf. Souto, La figura de Sócrates en Jenofonte, p. 122.

${ }^{107}$ Cf. Mem., I, 2, 3. En cuanto a que Sócrates ayudaba a sus discípulos, unas veces mediante acciones que mostraban su manera de ser y otras dialogando con ellos,

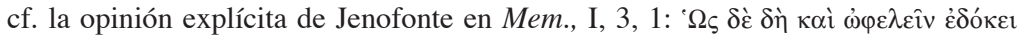

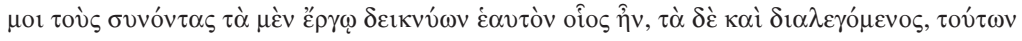

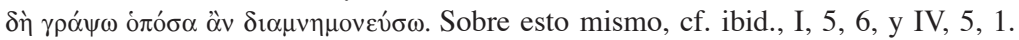

${ }^{108}$ Cf. Mem., I, 2, 6-7. En torno a que no cobraba, cf. también I, 2, 59-60, y Apol., 16.

${ }^{109}$ Cf. Mem., I, 2, 6. En III, 1, 1, Sócrates menciona a Dionisodoro, sofista que llegó a Atenas y daba clases de mando militar, pero en realidad se limitaba a ense-
} 
Como pensaba que las virtudes se incrementan y reafirman gracias al aprendizaje y a la práctica, ${ }^{110}$ sostenía que por buena que sea la naturaleza del ser humano, es necesario que

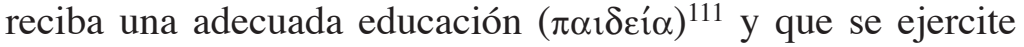
para alcanzar la virtud. ${ }^{12}$ Únicamente dichas naturalezas una vez educadas pueden conseguir las metas más altas, de lo contrario, su propia arrogancia y su vehemencia las arrastra a lo peor. ${ }^{113}$ Agregaba que quienes conocen lo bueno pero no lo practican, no son sabios ni virtuosos; porque lo justo es bueno y aquellos que lo conocen no pueden elegir otra cosa; ya que la justicia, como toda forma de virtud, es sabiduría. ${ }^{114}$ Sócrates tildaba de necia a toda persona que creyera que sin

ñar únicamente táctica (III, 1, 5). En III, 1, 11, el maestro de Jenofonte le aconseja al muchacho que regrese con dicho sofista para ver si se avergüenza por haberle cobrado y haberlo despedido con tan pocos conocimientos.

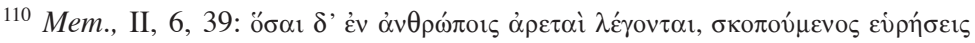

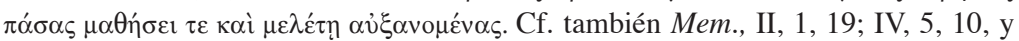

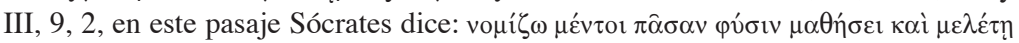

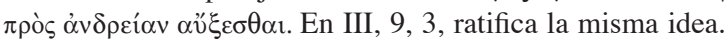

${ }^{111}$ Cf. Mem., IV, 1, 4-5.

112 Cf. Mem., I, 2, 19-23.

${ }^{113}$ Cf. Mem., IV, 1, 2-5. Al respecto, Sócrates "No se dirigía [...] a todos por igual, sino que a quienes pensaban que gozaban de una buena disposición natural y despreciaban la enseñanza, les explicaba que las que pasan por ser las mejores naturalezas son las que más educación necesitan [...]. De la misma manera, los hombres con mejores disposiciones naturales, con mayor fuerza de espíritu y eficaces al máximo en lo que emprenden, si se les educa e instruye en lo que tienen que hacer resultan excelentes y utilísimos, pues llevan a cabo los más numerosos y mejores servicios, pero si no se les educa ni se les instruye, son los peores y los más dañinos: no saben discernir lo que tienen que hacer, se lanzan a muchos negocios funestos, y como son altivos y violentos, resultan difíciles de manejar y de disuadir, con lo que causan muchos y terribles males" (Mem., IV, 1, 2-4, sigo la traducción de Gredos). Hay que aclarar que Sócrates no creía en una superioridad hereditaria, sino en la inteligencia humana en general; en otras palabras, la aristocracia se fundamenta en la areté, no en la sangre (cf. Rodríguez Adrados, Ilustración y política en la Grecia Clásica, pp. 501 y 519). Cf. Mem., III, 9, 3: "tanto los más dotados como los más obtusos por naturaleza, deben recibir enseñanzas y practicar en aquellas actividades en las que quieran llegar a ser dignos de renombre" (sigo la traducción de Gredos).

${ }^{114}$ Cf. Mem., III, 9, 4-5. 
educación podía elegir lo más útil para sí mismo, o a quien sin conocer lo más útil creía firmemente que estaba haciendo lo correcto. ${ }^{115}$

El filósofo reconocía el buen natural de alguien a partir de su facilidad para entender, aprender y recordar, y por su afán de saber acerca de la administración de la casa y del Estado; pues consideraba que tales hombres, una vez educados, procurarían la felicidad no sólo de su casa sino también de los demás hombres y de las ciudades. ${ }^{116}$ Pensaba que el conocimiento es sabiduría. ${ }^{117}$

En opinión de Salay, más que probar que Sócrates no corrompía a sus adeptos, Jenofonte proporciona numerosos ejemplos de cómo su maestro los hacía mejores. Según este estudioso, al enumerar las virtudes de Sócrates Jenofonte hace una larga lista de los vicios de los ciudadanos atenienses. ${ }^{118}$ De acuerdo con el jefe de los Diez Mil, su maestro se preocupaba más por enseñarles a sus acompañantes la virtud y el buen juicio antes que la elocuencia o la administración, para evitar así que incurrieran en la injusticia y en malas acciones. ${ }^{119}$

Conviene señalar que el filósofo creía que en nada es inferior la naturaleza femenina a la del varón, salvo en su falta de juicio y fuerza física; en su opinión es el hombre quien debe enseñarle a su mujer lo que quiere que ella sepa. ${ }^{120}$ Como bien observa Souto, el Sócrates de Jenofonte deja entrever las ideas feministas de este autor, pues considera que tanto el esposo como la esposa deben educar a los hijos. ${ }^{121}$ En el

\footnotetext{
115 Cf. Mem., IV, 1, 5.

116 Cf. Mem., IV, 1, 2.

117 Cf. Mem., IV, 6, 7.

${ }^{118}$ Cf. Salay, Socrates the whipping post: Xenophon's portrayal of Socrates as a rebuke of Athenian Society, pp. 59-60.

${ }^{119}$ Cf. Mem., IV, 3, 1.

${ }^{120}$ Cf. Symp., II, 9.

${ }^{121}$ Cf. Mem., II, 2, 4-6, así como Oec., VII, 12 y 30. Cf. Souto, La figura de Sócrates en Jenofonte, p. 414.
} 
Económico el filósofo ágrafo menciona que los maridos son los principales maestros de sus esposas, por lo tanto, son los responsables de los errores que ellas cometen a causa de una educación deficiente. ${ }^{122}$

En términos generales, el maestro de Jenofonte sostenía que quien enseña a hablar y actuar como es debido, con justa razón se hacía merecedor de los honores que se les daba a Quirón y Fénix. ${ }^{123}$

- En cuanto a su postura sobre la pederastia, Sócrates solía enamorarse de hombres de buen aspecto, que aspiraban a la virtud. ${ }^{124}$ El filósofo se ufanaba de infundir en sus enamorados el deseo de ser más virtuosos: por ejemplo, más liberales en lo que respecta al dinero, más amantes del esfuerzo, deseosos de gloria, más modestos y discretos. ${ }^{125}$

En el Simposio, Sócrates habla con afán pedagógico acerca del amor, alude a Afrodita Urania y a Afrodita Vulgar, la primera rige el amor espiritual, la amistad y las bellas acciones, mientras la otra preside el amor corporal ('A $\varphi \rho \circ \delta i ́ \tau \eta ~ O ’ \rho \alpha v i ́ \alpha \tau \varepsilon \kappa \alpha i$

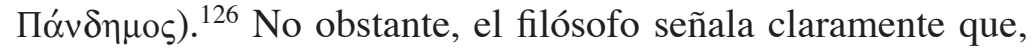
si el amante quiere tener un buen amado, tiene que ejercitarse en la virtud, pues, si él mismo es una persona ruin, no puede mejorar a su amado ni ser buen ejemplo para él. ${ }^{127}$

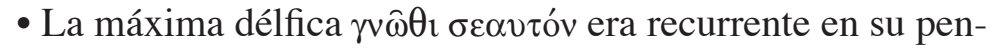
samiento. En su opinión, el verdadero conocimiento se ob-

\footnotetext{
${ }^{122}$ Cf. Oec., III, 11, 14; VII, 4, 10, 18, 20 y 22; VIII, 2; IX; X, 1; XI, 4. Cf. la opinión de Pomeroy, en Xenophon, Oeconomicus. A social and Historical Commentary, pp. 78-84. Para más detalles en torno a la educación femenina, cf. Joana Zaragoza Gras, "La mujer en el Económico de Jenofonte", Actas del IX Simposio de la Sociedad Española de Literatura General.

${ }^{123}$ Cf. Symp., VIII, 23.

${ }^{124}$ Cf. Symp., VIII, 41. Sin embargo, al aludir concretamente a los ejércitos tebano y eleo, formados por amantes, Sócrates sostiene que eso era algo muy vergonzoso (cf. VIII, 34).

${ }^{125}$ Cf. Symp., IV, 15.

${ }^{126}$ Cf. Symp., VIII, 9-41.

${ }^{127}$ Cf. Symp., VIII, 26-27.
} 
tiene cuando uno se analiza a sí mismo; ${ }^{128}$ ya que nada más quien está consciente de sus virtudes y de sus defectos puede alcanzar la fama, pues los demás la pierden víctimas de sus errores. ${ }^{129}$ Decía que el no conocerse uno mismo y el opinar sobre lo que uno no sabe se asemeja a la locura. ${ }^{130}$ Para el filósofo la máxima escrita en el templo de Apolo busca que el hombre sepa con exactitud cuáles son sus propias capacidades y cuáles sus propias limitantes, a fin de evitar en lo posible los peligros y los obstáculos que la vida le presenta. ${ }^{131} \mathrm{En}$ este sentido, el conocimiento de uno mismo se traduce en el descubrimiento de la propia ignorancia y en la búsqueda de la virtud. ${ }^{132}$ Casi al final de Memorables, Sócrates alude explícitamente a la inscripción $\Gamma v \hat{\omega} \theta$ r $\sigma \varepsilon \alpha v \tau$ tóv, entre sus comentarios destaca que quien desconoce su propio valor se desconoce a sí mismo, este tipo de personas no saben ni siquiera lo que les conviene, a menudo fracasan y se precipitan a la desgracia, con todo ello se ganan la mala fama, la burla y el desprecio de los demás. ${ }^{133}$

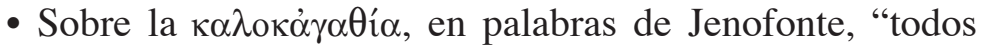
los maestros muestran a sus discípulos de qué manera hacen lo que enseñan y los conducen por medio de la palabra ${ }^{134}$

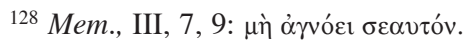

${ }^{129}$ Cf. Mem., IV, 2, 25-29. La misma idea se encuentra esbozada en III, 9, 6.

${ }^{130}$ Cf. Mem., III, 9, 6.

${ }^{131}$ De acuerdo con Ruffino, sobre todo a partir de Memorables Sócrates ha pasado a la historia como un "moralista" y como "filósofo popular", que trata de encontrar el modo más aceptable y conveniente de pasar la vida (cf. Socrate: L'uomo e i tempi, pp. 99-100). Según este autor, la sentencia implica aceptar que no se sabe, y el acto de conocer debe partir de una buena disposición ética, en otras palabras, admitir que no se sabe y el empeño en conocerse a sí mismo (cf. Ruffino, ibid., p. 114).

${ }^{132}$ Cf. Rodríguez Adrados, Ilustración y política en la Grecia Clásica, p. 499.

${ }^{133}$ Cf. Mem., IV, 2, 24-29.



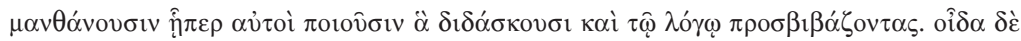

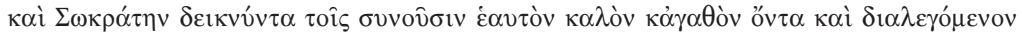

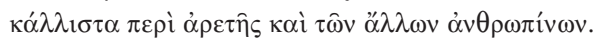


y de inmediato da su testimonio. Es oportuno recordar que gracias a su ejemplo, Sócrates alejó a muchos jóvenes de los vicios, les hizo anhelar la virtud y los animó a cuidar de sí mismos, para que al imitarlo llegaran a ser hombres de bien

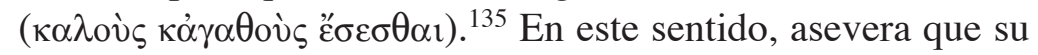
maestro se mostraba a sus seguidores como un hombre $\kappa \alpha \lambda$ ò

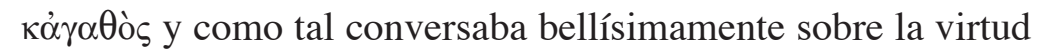
y las otras cualidades humanas. En torno a lo que Sócrates pensaba que debía saber un hombre bello y bueno, él mismo se preocupaba por enseñar lo que sabía, cuando no dominaba algún tema los mandaba con algún experto. ${ }^{136}$ Afirmaba que

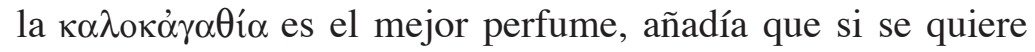
ser virtuoso hay que frecuentar a quien sea capaz de hacerle practicar a uno la virtud. ${ }^{137}$ La rectitud forma parte de dicho comportamiento noble. ${ }^{138}$ Los dioses también se complacen

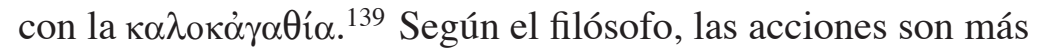
convincentes que las palabras. ${ }^{140}$ Para ratificarlo, Jenofonte afirma que a través de su propio ejemplo, Sócrates volvía a sus compañeros más piadosos, virtuosos y prudentes. ${ }^{141}$ En otro pasaje añade que su maestro conducía a sus oyentes a la

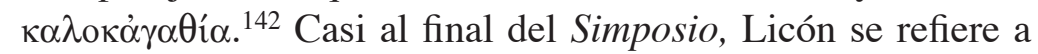

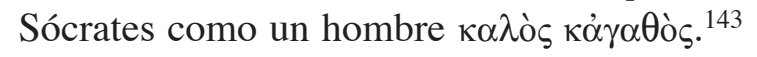

${ }^{135}$ Cf. Mem., I, 2,2 y 3. Ver igualmente Mem., I, 3, 1: "ayudaba a sus discípulos, unas veces mediante acciones que mostraban su manera de ser y otras dialogando con ellos". Sobre esto mismo, cf. ibid., I, 5, 6, y IV, 5, 1.

${ }^{136}$ Cf. Mem., IV, 7, 1, y Oec., II, 15-16, por sólo mencionar algunos ejemplos.

${ }^{137}$ Cf. Symp., II, 4-5.

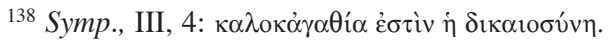

${ }^{139}$ Cf. Symp., IV, 49.

${ }^{140}$ Cf. Mem., IV, 4, 10.

${ }^{141}$ Cf. Mem., IV, 3, 18.

${ }^{142} \mathrm{Cf}$. Mem., I, 6, 14. Jenofonte afirma que no había nada más provechoso que frecuentar a su maestro, debido a que mediante sus enseñanzas Sócrates siempre era útil y les hacía bien a quienes lo trataban (cf. IV, 1, 1). Eî̀

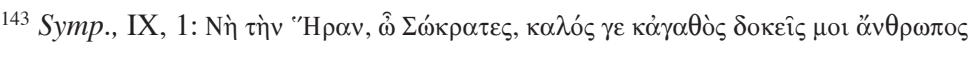




\section{Conclusiones}

Pese a las dudas acerca de qué tanto Jenofonte supo comprender a su maestro y hasta qué grado formó parte del círculo socrático, son evidentes los puntos que retoma. Con base en lo expuesto hasta aquí, me adhiero sobre todo a la postura de Luccioni y de Palacios Roa, pues considero que Sócrates influyó decisivamente en la formación intelectual y moral de Jenofonte, quien adoptó varias ideas de su maestro a causa de que estaba de acuerdo con ellas, ya que coincidían con su propia naturaleza y con su propia forma de pensar. Su visión de Sócrates es la interpretación de un hombre culto, que tuvo el privilegio de ser educado por este sabio. Si bien el hijo de Grilo está más interesado en la aplicación práctica de los preceptos socráticos a la vida cotidiana que en la mera especulación, es en este matiz práctico donde radica la originalidad de Jenofonte. De modo que, al componer sus obras, este autor evoca las ideas de Sócrates precisamente porque estaba de acuerdo con ellas y porque le constaba que eran válidas. En este sentido, su relación con el filósofo le resultó provechosa y vio su filosofía como una doctrina práctica y digna de ejercicio. Desde mi punto de vista, conservó para sí aquello acorde con su forma de pensar; añadiendo a las lecciones de su maestro lo que había aprendido gracias a su experiencia directa y también lo que le transmitieron otras personas.

Como dice Luccioni, su filosofía representa un caso peculiar de influencia socrática: permite medir la acción ejercida por Sócrates sobre un espíritu mediano y un alma mediana. Sin embargo, además de su espíritu mediano, Jenofonte tenía a la vez un buen sentido común, cultura e inteligencia. ${ }^{144}$ Así mismo, considero que tras el contacto con Sócrates y sus ideas morales experimentó en persona la trascendencia de mu-

\footnotetext{
${ }^{144}$ Cf. Luccioni, Xénophon et le socratisme, p. 171.
} 
chos de los preceptos socráticos, tales como el ser congruente entre lo que se dice y lo que se hace, el valor del esfuerzo, el autodominio, la amistad, la prudencia, la justicia, la piedad, etcétera; de manera que, al integrarse al ejército de Ciro el Joven, a causa de la guerra adoptó varias virtudes de su maestro, las puso en práctica y las reafirmó por convicción propia.

En suma, considero que el juicio de García Bacca, según el cual el Sócrates jenofóntico es el término medio entre el hombre ordinario y el hombre-diosecillo platónico, retrata con mayor exactitud al hijo de Sofronisco; ya que Jenofonte

lo presenta tan amable, tan interesado por las cosas más corrientes para dignificarlas con valor humano, tan preocupado por los amigos, por su educación en sabiduría humana, tan medido en sus pretensiones, aun científicas, que parece haberse propuesto la faena de centrar todo en el hombre, y al hombre en sí mismo. ${ }^{145}$

\section{BIBLIOGRAFÍA}

\section{Fuentes antiguas}

Diogenes LAERTIUS, Lives of eminent philosophers I, english transl. R. D. Hicks, Cambridge, Harvard University Press (The Loeb Classical Library), 1950, 550 págs.

Jenofonte, Anábasis, intr. Carlos García Gual, trad. y nts. Ramón Bach Pellicer, Madrid, Gredos (Biblioteca Clásica Gredos, 52), 1991.

_, La vida y las doctrinas de Sócrates, vers. castellana y nota preliminar José Deleito y Piñuela, Valencia (España), Prometeo, 1966.

-, Recuerdos de Sócrates, Económico, Banquete, Apología de Sócrates, introds., trads. y notas de Juan Zaragoza, Madrid, Gredos (Biblioteca Clásica Gredos, 182), 1993.

-, Socráticas. Economía. Ciropedia, est. prel. David García Bacca, México, CONACULTA-OCÉANO, 1999.

${ }^{145}$ Cf. el estudio preliminar de García Bacca en Jenofonte, Socráticas. Economía. Ciropedia, p. XV. 
Senofonte, Ipparchico. Manuale per il comandante di cavalleria, intr., trad. y nts. Corrado Petrocelli, appendice: P. G. Joly de Maizeroy. Cuadro generale della cavalleria greca, Bari, Edipuglia (Quaderni di "Invigilata lucernis", 14), 2001.

Xenophon, Memorabilia, Oeconomicus, transl. by E. C. Marchant, Symposium, Apology, transl. by O. J. Todd, Cambridge, Harvard University Press, 2002.

-, Oeconomicus. A social and Historical Commentary, new english transl. Sarah B. Pomeroy, Oxford, Clarendon Press, 1994.

\section{Bibliografía especializada}

Alegre, Antonio, La sofística y Sócrates. Ascenso y caída de la polis, Barcelona, Montesinos (Biblioteca de Divulgación Temática, 37), 1986.

Anderson, J. K., Xenophon, London, Bristol Classical Press, 2001 (1a. ed., 1974).

ColaiAco, James A., Socrates against Athens, New York-London, Routledge, 2001.

Dobson, J. F., La educación antigua, trad. de Vicente Paul Quintero, Buenos Aires, Editorial Nova, 1947.

GRAU, Sergi, "Modelos de conversión e iniciación a la filosofía: un análisis de un tipo biográfico", Noua tellus, 26.2, México, UNAM, 2008, pp. 67-102.

GRAY, Vivienne J., "The Framing of Socrates, the literary interpretation of Xenophons Memorabilia”, Hermes, Einzelschriften, 79, Stuttgart, Franz Steiner Verlag, 1998.

JAEGER, Werner, Paideia. Los ideales de la cultura griega, II, vrs. española Wenceslao Roces, México, Fondo de Cultura Económica, 1944.

- Paideia. Los ideales de la cultura griega, III, vrs. española Wenceslao Roces, México, Fondo de Cultura Económica, 1949 (2a. ed. esp.).

Galino, María Ángeles, Historia de la educación. Edades antigua y media, Madrid, Gredos, 1988 (2a. ed., 3a. reimp.).

Gish, Dustin Avery, Xenophon's Socratic rhetoric: A study of the "Symposium", University of Dallas, 2003 (tesis doctoral).

Gómez-Lobo, La ética de Sócrates, México, Fondo de Cultura Económica (Cuadernos de la Gaceta, 56), 1989.

Humbert, Jean, Socrate et les petits socratiques, Paris, Presses Universitaires de France, 1967.

Huss, Bernhard, "The dancing Sokrates and the laughing Xenophon, or the other Symposium”, American Journal of Philology, 120, 1999, pp. 381-409. 
LESKY, Albin, Historia de la literatura griega, Madrid, Gredos, 1976.

LuCCIONI, Jean, Xénophon et le socratisme, Paris, Presses Universitaires de France, 1953.

NúÑEZ GuZMÁn, Ricardo, El Banquete de Jenofonte, intr., trad. y nts., México, Facultad de Filosofía y Letras, Universidad Nacional Autónoma de México, 1994 (tesis inédita).

Olivares Chávez, Carolina, Ética y milicia en Acerca del hiparco de Jenofonte, estudio, traducción y notas, México, Facultad de Filosofía y Letras, UNAM, 2005 (tesis de maestría).

-, "La presencia de los dioses en el Hiparco de Jenofonte", Noua tellus, 26.1, 2008, pp. 91-113.

Palacios Roa, Alfredo, "Jenofonte: el hombre, el estratega y su obra", Limes, 19, 2007, pp. 162-173.

RodríGUEZ AdRADOS, Francisco, Ilustración y política en la Grecia Clásica, Madrid, Revista de Occidente, 1966.

RossetTi, Livio, Aspetti della letteratura socratica antica, Perugia, Chieti, 1977.

RuFfino, Antonio, Socrate: L'uomo e i tempi, Italia, Liguori Editore, 1971.

SalaY, Paul W., Socrates the whipping post: Xenophon's portrayal of Socrates as a rebuke of Athenian Society, California State University, 2004 (tesis de Maestría en Artes).

SAlomone, Serena, "Letteratura, tradizione e novità tattico-strategique nello Hipparchikos di Senofonte", en Maia. Rivista di letterature classiche, nuova serie/fascicolo III, anno XXXVIII, settembre-dicembre, Bologna, Nuova Casa Editrice Licinio Cappelli, 1986, pp. 197-205.

Souto Delibes, Fernando, La figura de Sócrates en Jenofonte, Madrid, Universidad Complutense de Madrid, tesis doctoral leída el 15-06-2000. El texto completo, disponible en PDF, se puede consultar en: www.ucm. es/BUCM/tesis/19972000/H/3/H3074102.pdf (consultado el 4 de enero de 2007).

Zaragoza Gras, Joana, "La mujer en el Económico de Jenofonte", Actas del IX Simposio de la Sociedad Española de Literatura General, 1994, vol. 1, pp. 401-406. 